\section{Evaluation of a pamphlet on visceral leishmaniasis as a tool for providing disease information to healthcare professionals and laypersons}

\author{
Avaliação de um folheto sobre leishmaniose \\ visceral como instrumento para fornecer \\ informações a profissionais de saúde e leigos
}

\author{
1 Centro de Pesquisas René \\ Rachou, Fundação Oswaldo \\ Cruz, Belo Horizonte, Brazil. \\ Correspondence \\ Z. M. P. Luz \\ Laboratório de Pesquisa \\ Clínica, Centro de Referência \\ em Leishmaniose, Centro \\ de Pesquisas René Rachou \\ Fundação Oswaldo Cruz. \\ Av. Augusto de Lima 1715 \\ Belo Horizonte, $M G$ \\ 30190-002, Brasil. \\ profeta@cpqrr.fiocruz.br
}

\begin{abstract}
Although educational materials are frequently produced and used as part of control programs in Brazil, little is known about the efficacy of this type of information. This study evaluated the potential for disseminating information on visceral leishmaniasis using a pamphlet. The sample consisted of 551 healthcare workers and 379 laypeople from a metropolitan area located in southeast Brazil. Both before and after reading the pamphlet, subjects completed a multiple-choice questionnaire. Overall baseline knowledge of the disease was estimated by the proportion of correct answers before reading the pamphlet. Although specific knowledge among zoonosis control workers was higher $(90.0 \%$ on average), overall baseline knowledge of the disease varied from $45.0 \%$ to $77.0 \%$. After reading the pamphlet, the levels increased to $71.0 \%$ and $96.0 \%$, respectively. Before reading, the lowest proportion of correct answers in all groups related to the disease symptoms. Analysis of incorrect answers showed that visceral leishmaniasis is mainly confused with leptospirosis. The increased proportion of correct answers after reading the pamphlet is evidence of its potential as an educational tool.
\end{abstract}

Pamphlets; Visceral Leishmaniasis; Questionnaires; Health Personnel
Zélia Maria Profeta da Luz ${ }^{1}$

Virgínia Schall 1

Ana Rabello 1

\section{Introduction}

In Brazil, visceral leishmaniasis (VL), caused by Leishmania (Leishmania chagasi), is the most severe of the leishmaniases and can be fatal if untreated. In this country, as elsewhere in Latin America, increasing migration and urbanization have contributed greatly to the rise of $\mathrm{VL}$ as a major public health problem 1,2. Although the disease was historically found in rural areas, its epidemiological pattern has changed in the last 20 years. In some previously non-endemic large cities, VL incidence has been increasing $3,4,5$.

The Greater Metropolitan Area of Belo Horizonte in the State of Minas Gerais in Southeast Brazil has a population of 4,606,318 (http:// www.datasus.gov.br, accessed on 21/Mar/2003). Since the first reported case in 1989, VL cases have increased exponentially. Simultaneously, a geographic expansion of VL within Greater Metropolitan Belo Horizonte has been observed. As of 2002, $51.0 \%$ of the municipalities comprising this Greater Metropolitan Area reported autochthonous VL cases. Death from VL in Greater Metropolitan Belo Horizonte is common; the case-fatality rate is approximately $10.0 \%$. The low number of qualified healthcare professionals capable of making an early diagnosis and the resulting lack of prompt treatment contribute to this elevated case-fatality rate 5 . 
The leishmaniasis control program follows a limited and costly protocol focusing on treatment of human cases, intra-domiciliary application of insecticide, and sacrificing seropositive dogs. Awareness-raising strategies concerning the disease are needed at all levels of the community. Dissemination of VL information in an educational campaign using informative/educational materials such as handbooks, booklets, and pamphlets may be a valuable tool as an adjunct to healthcare service protocols and control programs. Nonetheless, in order to serve as effective teaching tools, these materials must be preceded by scientific investigation and produced within well-defined criteria. It is crucial that they provide tangible concepts which are presented with the target population's cognitive potential in mind 6 .

Although educational materials are frequently produced and used as part of control programs in Brazil, very little is known about the effectiveness of this kind of information. The low quality of available leishmaniasis information in Brazil (especially in booklets and pamphlets) has been discussed by Luz et al. 7 . These authors concluded that the 18 publications analyzed generally failed to provide bibliographies or properly identify the target readers or objectives. Moreover, the lack of appropriate illustrations and the presence of conceptual errors clearly undermined the information's impact.

This study presents an evaluation of knowledge among healthcare workers and laypeople both before and after reading an independently prepared informative pamphlet on VL.

\section{Methodology}

\section{Study area}

The study was carried out in Belo Horizonte, a city of 2,228,065 inhabitants and the capital of Minas Gerais State, and two other municipalities in Greater Metropolitan Belo Horizonte within approximately $30 \mathrm{~km}$ of the capital: $\mathrm{Ri}-$ beirão das Neves and Santa Luzia, with 278,572 and 199,450 inhabitants, respectively (http:// www.datasus.gov.br, accessed on 21/Mar/2003). In 2002, the number of reported cases (and the case-fatality rate) of VL were $75(11.0 \%)$ in Belo Horizonte, 21 (4.8\%) in Ribeirão das Neves, and 22 (4.5\%) in Santa Luzia. Figure 1 shows the location of these municipalities and the geographical expansion of VL in the region from 1989 to 2002.
Figure 1

A. Map of Brazil showing Greater Metropolitan Belo Horizonte (insert) in the State of Minas Gerais. B. Geographic expansion (light-gray area) of visceral leishmaniasis in the region from 1989 to 2002 .
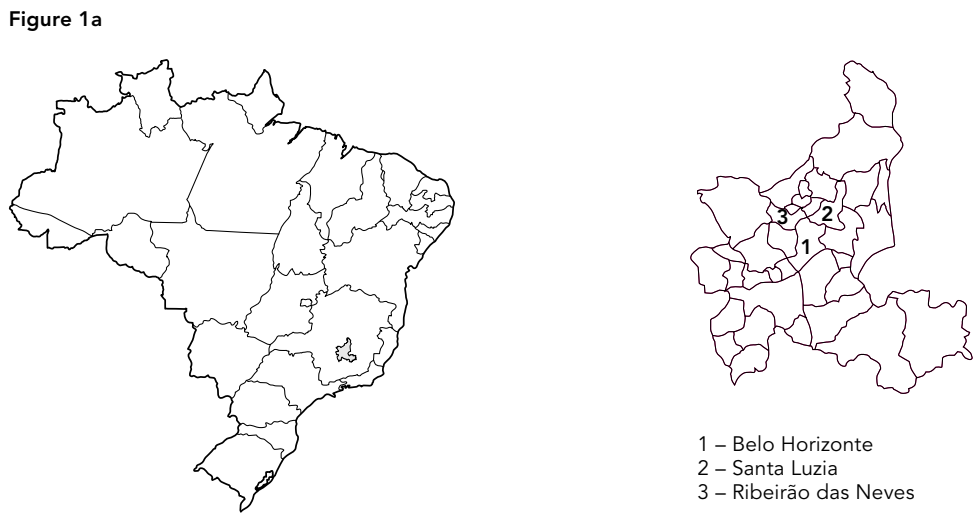

1 - Belo Horizonte 2 - Santa Luzia 3 - Ribeirão das Neves

Figure 1b
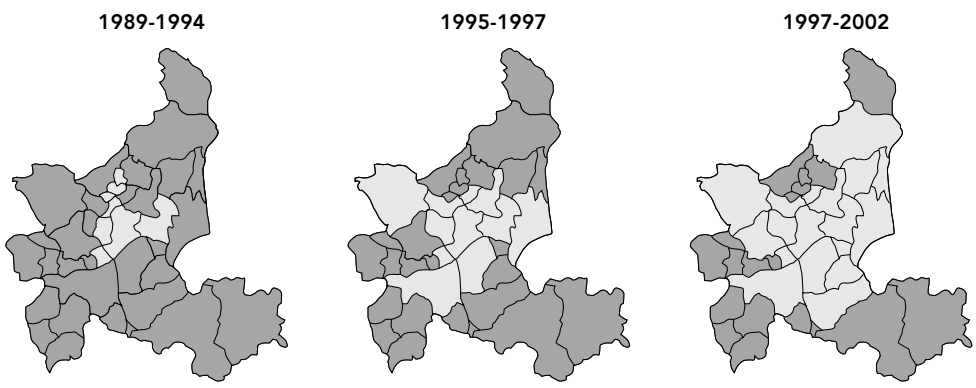

The pamphlet

Figure 2 shows the pamphlet's design. The material was developed by a team of professionals from the Leishmaniasis Reference Center at the René Rachou Research Center, Oswaldo Cruz Foundation, in partnership with a group of six healthcare workers (involved in surveillance activities) from various municipalities in Greater Metropolitan Belo Horizonte. In an attempt to avoid the errors and inadequacies generally found in this kind of material, the pamphlet was based on the results of our previous assessment of informative materials on leishmaniasis 7 . The population's prior information, and especially that of patients under treatment for VL at the Leishmaniasis Research Center, was also considered. The pamphlet highlights 

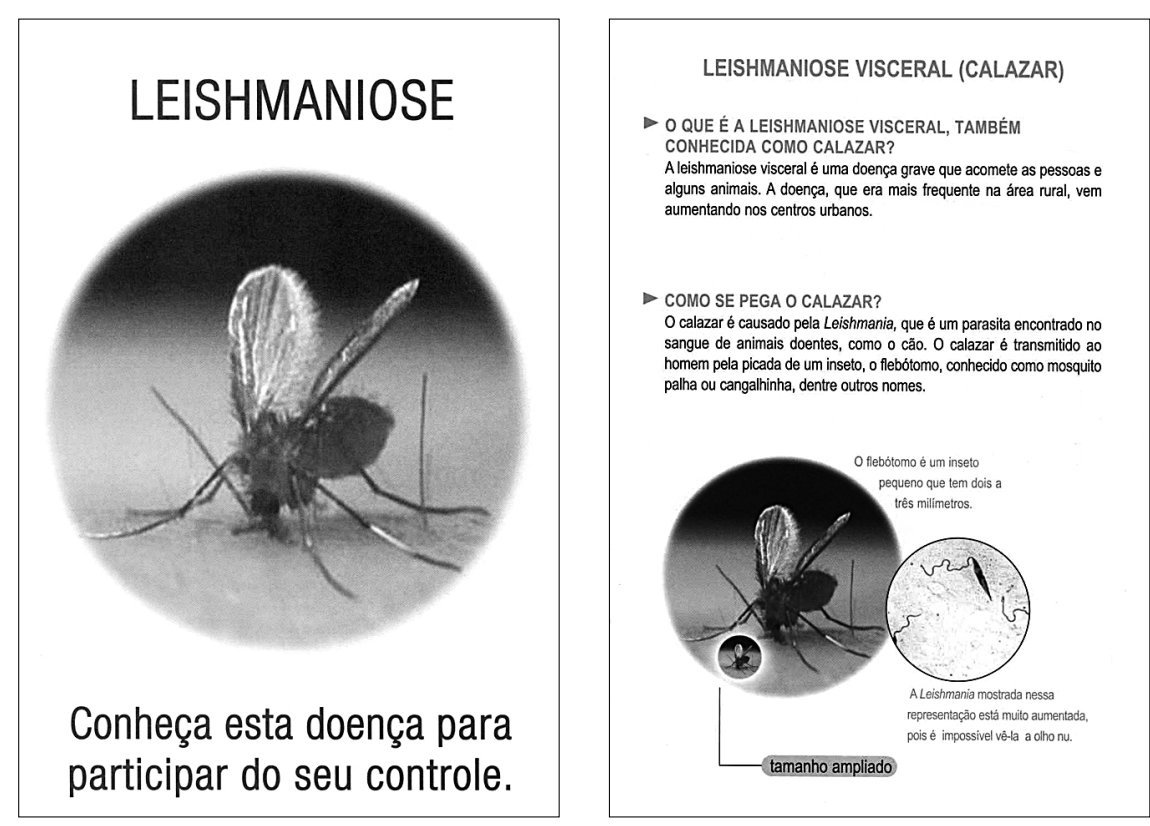

QUAIS SÃO OS PRINCIPAIS SINTOMAS DA DOENÇA?

\section{FEBRE DURANTE MUITOS DIAS}

PERDA DE APETITE, EMAGRECIMENTO

PALIDEZ

TOSSE SECA

FRAQUEZA

COM O PASSAR DO TEMPO O DOENTE APRESENTA AUMENTO DO FIGADO E DO BAÇO.

\section{$\triangle$ O CALAZAR É GRAVE E PODE MATAR!}

É necessário detectar a doença logo no seu início, pois, dessa forma

são evitadas suas complica̧̧ōes que levam à morte.

- O QUE FAZER?

Ao perceber os primeiros sinais do calazar, procure rapidamente 0 Posto de Saude mais perto da sua casa ou o seu Serviço de Saúde, para avaliação médica e, se necessário, realizar os exames especificos. Otratamento e gratuitio e o medicamento e encontrado na Secretaria de Saúde do município, após a confirmaçăo da doença.

\section{MUITA ATENÇÃO:}

COMOÉ FEITO O CONTROLE DA TRANSMISSĂO? O contole da transmissáo da doença e cocrdenado pela Secretaria de Saúde por meio da eliminaçăo dos căes comprovadamentie contaminados, do uso

- COMO PODEMOS AJUDAR NO CONTROLE? O Flebótomo gosta de locais úmidos, acúmulo de folhas, fezes de animais, restos de matéria orgánica em geral.

POR ISSO, ELIMINE O LIXO DE FORMA ADEQUADA MANTENHA A SUA CASA E O SEU QUINTAL SEMPRE LIMPOS NÄO JOGUE LIXO EM LOTES VAGOS

- EXISTEM LEIS QUE REGULAMENTAM AS AÇÖES SANITARIAS? Sim. E o năo-cumprimento, pelos profissionais de saúde,
proprietários de animais e demais cidadăos, das leis: federal $6437 \Pi 7$ e estadual $13317 / 99$, que regem as açōes sanitárias para controle da doença, podem implicar multas e advertências. DO GOVERNO E SEUS CIDADÃOS

QUANDO HOUVER DÚVIDAS, PROCURE A SECRETARIA DE SAÚDE DO SEU MUNICIPIO.
ZELAR PELA SAÚDE COLETIVA E RESPONSABILIDADE

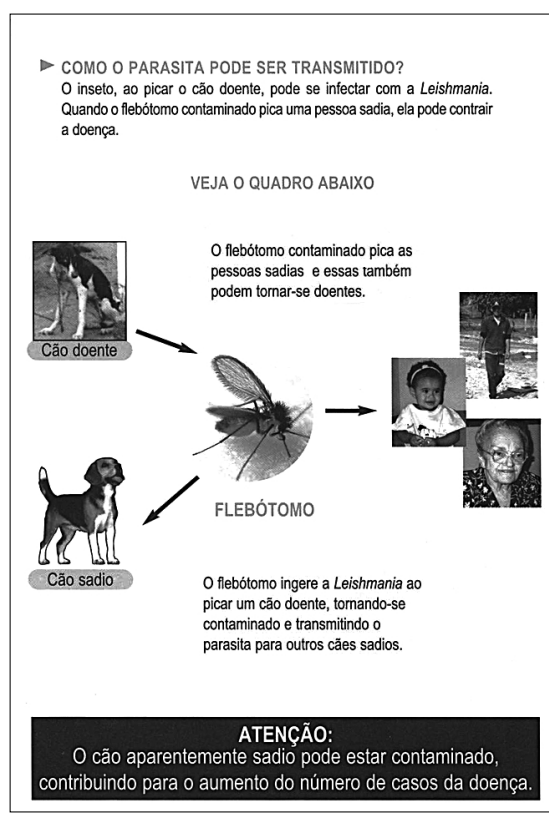

PERGUNTAS, SUGESTÖES E COMENTÁRIIOS PODEM SER ENVIADOS PARA Rede de Trabalhos em Leishmanioses do Centro de Reteréncia e Treinamento on Aesthmanioses do Centro de Pescuussas René Rachou da Flocruz Av. Augusto de Lima, 1715 - Barro Prêl

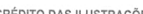

Flebotono

Esquema de
do CPRRR.

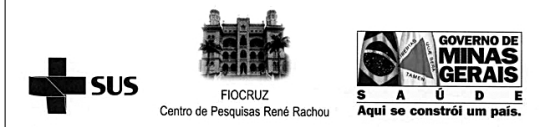


the main aspects of the disease, using accessible language and clear illustrations. The contents are divided into several topics, accompanied by short texts. Topics include leishmaniasis transmission mechanisms, the most evident symptoms, control measures, and instructions for seeking medical assistance.

\section{Questionnaires}

An anonymous, seven-question, multiple-choice questionnaire was used (Table 1), designed according to the general steps for questionnaires 8 . The concerns and recommendations of experienced local epidemiological-surveillance and health-education coordinators were also taken into account. In order to make the reasoning simple and straightforward, the questionnaire included all topics covered in the pamphlet, and the questions were listed in the same order in which the topics appear in the material. The same questionnaire was given to all participants both before and immediately after reading the pamphlet. General data such as age, gender, occupation, and schooling were collected. A group of 220 healthcare workers and students (from Belo Horizonte and Santa Luzia) who were not participating in the study graded the questionnaire. Scoring was based on level of clarity, considering the ratio of incorrect answers, non-responses, and multiple answers to the number of correct answers.

\section{Studied groups}

Nine hundred and twenty subjects were informed about the general objectives of the research and invited to participate. Two groups were studied. Group 1 consisted of healthcare workers: either community healthcare workers ( $n=309$ ) belonging to the Family Health Program (sponsored by the Brazilian Ministry of Health), zoonosis control agents $(n=190)$ (technical personnel involved in control activities), or nursing personnel $(n=52)$. Of the 52 nursing professionals, 15 (29.0\%) were registered nurses with university degrees, while the other $37(71.0 \%)$ had completed a technical training course as nurse technicians. Group 2 consisted of users of healthcare services $(n=30)$, teachers ( $n=126)$, and students from public elementary and high schools $(n=223)$. Previously standardized procedures were adopted to avoid bias in the results. All subjects participated voluntarily. The study lasted from June to December 2002 .
Table 1

Questionnaire given before and after reading the pamphlet.

Circle your answer for the following questions

1) Visceral leishmaniasis is known as...
a) Leprosy
b) Malaria
c) Dengue
d) Kala-azar
e) Leptospirosis

2) Visceral leishmaniasis is transmitted...
a) Through dog bites
b) Through the bite of the Aedes aegypti mosquito
c) Through the bite of the phlebotomus sandfly
d) Through mouse urine

3) The symptoms of visceral leishmaniasis in humans are...
a) Fever for several days, weight loss and coughing
b) Skin lesions
c) Fever, body aches, headache, conjunctivitis
d) Increase fingernail and hair growth

4) Visceral leishmaniasis is a disease that requires...
a) That people and dogs be vacinated
b) No treatment
c) Immediate treatment
d) Treatment only in the later phase of the disease

5) What you need to do when you perceive the symptoms of the disease?
a) Stay in bed and drink a lot of liquid
b) See a doctor
c) Talk to a pharmacist
d) Take fever and pain medication

6) How can you help with the control measures?
a) Don't eat raw meat
b) Cover the water tank and don't let any water stagnate
c) Keep the area outside the dwelling clean
d) Use shoes and gloves when dealing with the grease trap
e) Stay away from contaminated water

7) How is the disease controlled?
a) By eliminating stagnant water, vaccinating of dogs and treating patients
b) By eliminating triatominae and snails and treating patients
c) By eliminating dogs and treating patients
d) By eliminating scorpions and rats and treating patients 


\section{Data analysis}

Answers from the questionnaires and all participant data were analyzed with Epi Info 6.0. For comparison of the proportion of correct answers, the chi-square test with a 0.05 level of significance was used.

\section{Results}

\section{Potential for transmission of knowledge}

The study subjects from Belo Horizonte included 309 community healthcare workers, 190 zoonosis control agents, 126 teachers, 223 public elementary and high school students, and 30 users of healthcare services. The city of Belo Horizonte is administratively divided into nine regions, and the users of healthcare services were all from the same region. The other subjects were from seven different regions. Nurses were all from Ribeirão das Neves. Approximately $60.0 \%$ of participants were female healthcare professionals. Table 2 shows the frequency and proportions of all samples evaluated, as well as the participants' occupation and gender. Among healthcare workers, the majority $(89.0 \%$ of community healthcare workers, $46.0 \%$ of zoonosis control agents, and $55.0 \%$ of nurses) had worked at the same job for 1 to 5 years (mean $=2$ years). Median age of public elementary and high school students was 16 years, ranging from 13 to 41 . Thirty (14.0\%) and 129 (58.0\%) of the students were $6^{\text {th }}$ and $8^{\text {th }}$ graders, respectively. Another 61 were high school freshmen and sophomores, $32(14.0 \%)$ and $29(13.0 \%)$, respectively. Three (1.4\%) of the students did not inform their grade level. Among the teachers, 23 (18.0\%) were science teachers. Users of healthcare service con- sisted mainly of women $(87.0 \%)$, with a median age of 48 years (range $21-73$ ), and $52.0 \%$ were housewives, while the others had various occupations such as commercial workers, seamstresses, providers of general services, etc.

Baseline knowledge of the disease as estimated by the proportion of correct answers before reading the pamphlet varied considerably. With the exception of zoonosis control agents, who averaged $90.0 \%$ correct answers, scores among healthcare professionals (community healthcare workers) varied from $66.0 \%$ to $77.0 \%$. Teachers showed a similar profile $(64.0 \%$ correct). Users of healthcare services and public elementary and high school students presented poor knowledge of the disease $(45.0 \%$ correct answers). However, reading the pamphlet significantly improved performance among community healthcare workers, zoonosis control agents, nurse technicians, teachers and students, as shown in Table 3. After reading, lower numbers of non-responses and multiple answers were observed.

Before reading the pamphlet, the topic with the lowest number of correct answers was leishmaniasis symptoms (question 3 ). This was true for all groups, including healthcare professionals (Figures 3 and 4). Concerning need for treatment and control measures (questions 4 and 7 , respectively), no differences were observed in responses by nurses before and after reading the pamphlet. Among students, no differences were observed in question 4. Among healthcare users, no statistical differences were observed in questions 4,6 , or 7 before or after reading. On question 5 (what patients are expected to do when they note symptoms of the disease), high percentages of participants chose the correct response both before and after reading the pamphlet. Incorrect answers were also

Table 2

Occupation and gender of participants in a study on a leishmaniasis pamphlet $(\mathrm{n}=930)$.

Greater Metropolitan Belo Horizonte, Minas Gerais, Brazil.

\begin{tabular}{|c|c|c|c|c|c|c|}
\hline \multirow[t]{2}{*}{ Categories evaluated } & \multirow{2}{*}{$\begin{array}{l}\text { Number of } \\
\text { participants }\end{array}$} & \multirow[t]{2}{*}{$\%$} & \multicolumn{4}{|c|}{ Gender } \\
\hline & & & Female & $\%$ & Male & $\%$ \\
\hline Community healthcare workers & 309 & 33.2 & 269 & 87.0 & 40 & 13.0 \\
\hline Zoonosis control agents & 190 & 20.4 & 11 & 6.0 & 179 & 94.0 \\
\hline Nursing personnel* & 52 & 5.6 & 49 & 94.0 & 3 & 6.0 \\
\hline Teachers & 126 & 13.5 & 110 & 89.0 & 14 & 11.0 \\
\hline Students & 223 & 24.0 & 112 & 50.0 & 110 & 49.0 \\
\hline Users of healthcare services & 30 & 3.2 & 26 & 87.0 & 4 & 13.0 \\
\hline
\end{tabular}

* Nursing personnel (registered nurses with university degrees $=15$; nurse technicians $=37$ ). 
Average percentage of correct, multiple-answer, or blank questions among individuals before and after reading the leishmaniasis pamphlet. Greater Metropolitan Belo Horizonte, Minas Gerais, Brazil.

\begin{tabular}{|c|c|c|c|c|c|}
\hline \multirow[t]{2}{*}{ Categories evaluated } & \multicolumn{3}{|c|}{ Correct answers } & \multicolumn{2}{|c|}{$\begin{array}{l}\text { Non-responses or } \\
\text { multiple answers }\end{array}$} \\
\hline & Before & After & $p$ value & Before & After \\
\hline Community healthcare workers & 66 & 92 & $<0.001$ & 2 & 1 \\
\hline Zoonosis control agents & 90 & 96 & 0.02 & 9 & 1 \\
\hline Registered nurses & 72 & 90 & 0.327 & 9 & 1 \\
\hline Nurse technicians & 66 & 89 & 0.012 & 13 & 2 \\
\hline Teachers & 64 & 91 & $<0.001$ & 5 & 1 \\
\hline Students & 45 & 74 & $<0.001$ & 4 & 1 \\
\hline Users of healthcare services & 45 & 71 & 0.06 & 16 & 9 \\
\hline
\end{tabular}

evaluated for all participant categories. To present these results, groups were divided into two categories: healthcare workers in group 1 and participants from the other three occupations in group 2. Average percentages before and after reading the pamphlet are depicted (see Figure 5 for questions 1 to 7). On three questions $(4,6$, and 7$)$, reading the pamphlet failed to improve the participants' understanding.

Before reading, VL was mainly confused with leptospirosis by both groups. Ten per cent of group 1 responded that dogs are the vector for leishmaniasis when answering question 1 , a misconception related to the disease's transmission. In group 2, a similar proportion thought that VL could be transmitted through mouse urine (question 2). High percentages of respondents in both groups believed either that VL symptoms result from injuries or are similar to classic dengue symptoms. On the topic of treatment (question 4), high percentages in group 1 and group 2 chose vaccination as the correct course. However, the pamphlet did not address this point, and $6.0 \%$ of group 1 and $20.0 \%$ of group 2 insisted on giving the same incorrect response. In addition, nearly $11.0 \%$ of group 1 thought that treatment is only necessary in the later phase of the disease. On question 5, low percentages of both groups chose incorrect answers, and respondents in group 2 continued to give the same answers after reading. The last two questions (6 and 7) related to control measures. Before and after reading, both groups thought that VL control measures were the same as those for dengue.

\section{Discussion}

Parasitic and zoonotic diseases have become increasingly prominent due to urban encroachment into the natural environment and extensive population mobility. Urbanization rates have multiplied, and this trend has served to draw typically rural diseases into urban areas where concentrations of human and vector populations increase the incidence of infection 9. In Brazil, this increased urbanization is closely associated with the sharp increase in VL in urban areas 10 . In general, people migrate to large cities in pursuit of better living conditions. However, in the poorer outlying neighborhoods with various risk factors such as vector presence and inadequate sanitation, transmission can easily occur 1 . Clinical manifestations of VL vary from disfiguring lesions and scars to death. Severe epidemics with high case-fatality rates would have serious social and public health consequences.

The intrinsic complexity of visceral leishmaniasis, environmental conditions, and the socio-political and economic context call for prevention and control strategies that involve healthcare authorities working in close association with citizens. In addition, such strategies must take the population's knowledge base, beliefs, perceptions, and practices into account 9 .

This paper has attempted tried to outline a framework of knowledge on leishmaniasis in Greater Metropolitan Belo Horizonte, where VL is a relatively new public health problem and mainly affects poor people. Although the number of cases has increased, medical and allied healthcare personnel are often unfamiliar with the disease, and despite control measures the average number of fatal cases is relatively high. 
Figure 3

Percentage of health community workers (a), zoonosis control agents (b), nurse technicians (c), and registered nurses

(d) who correctly answered questions 1 to 7 before and after reading the pamphlet.

Figure $3 a$

Health community workers $(n=309)$

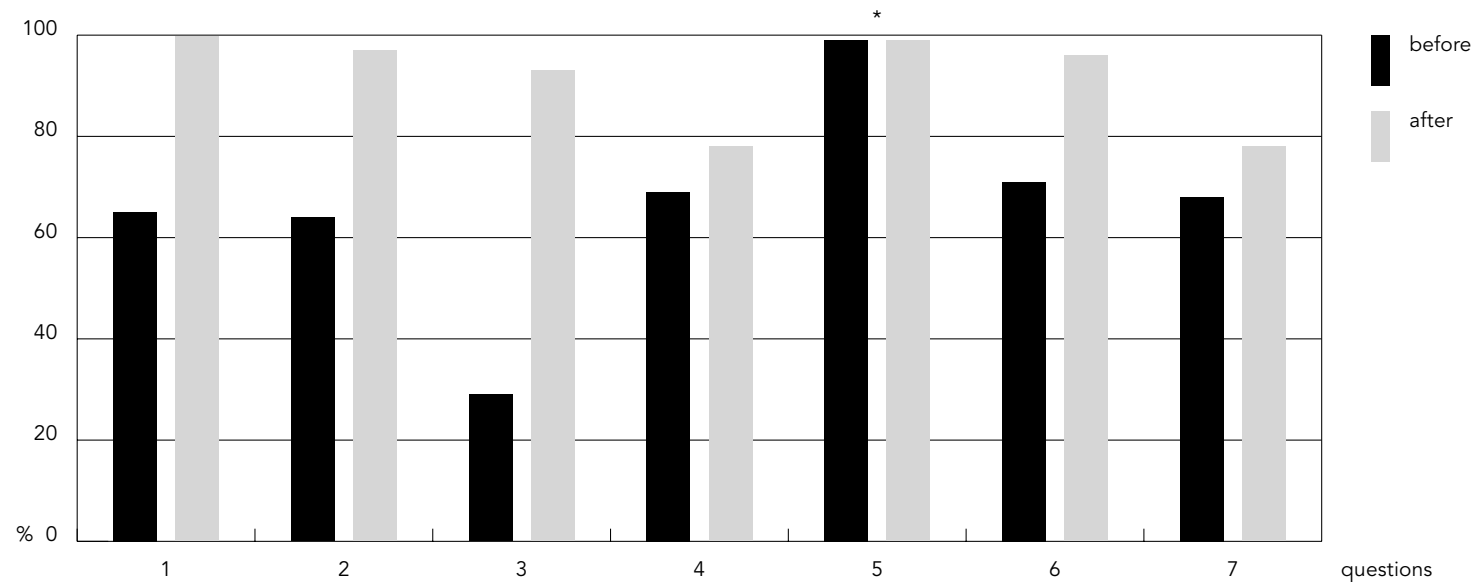

Figure $3 b$

Zoonosis control agents $(n=190)$

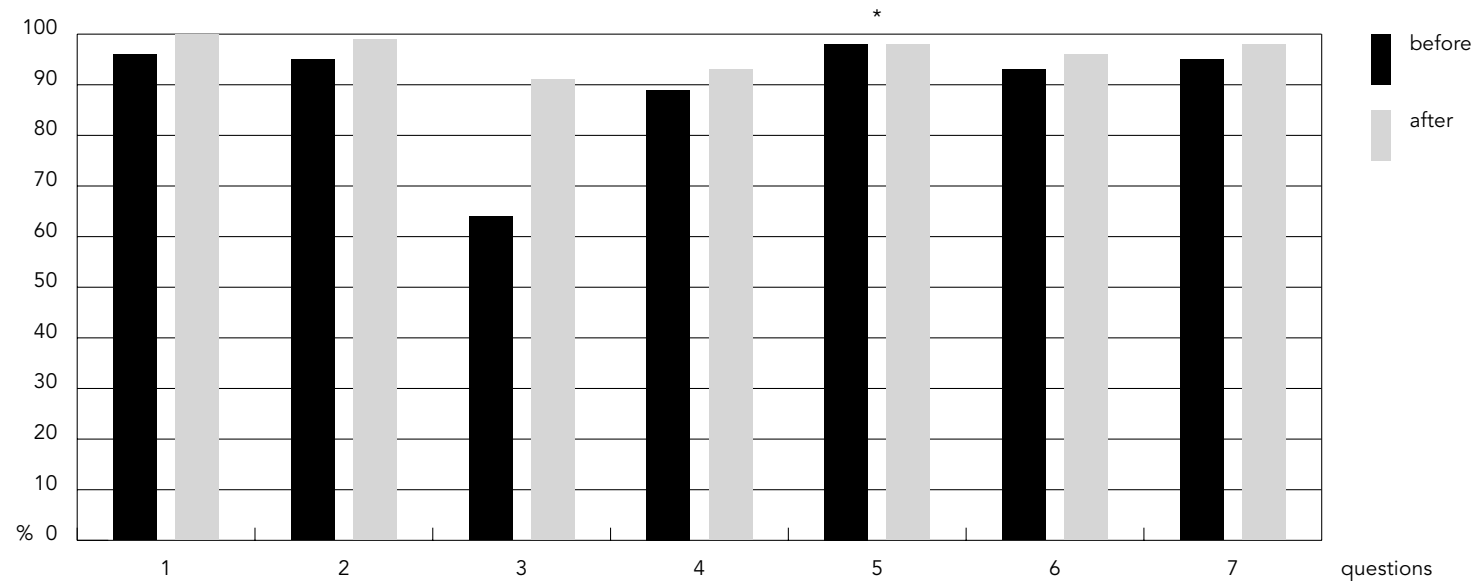

(continues) 
Figure 3c (continued)

Nurse technicians $(n=37)$

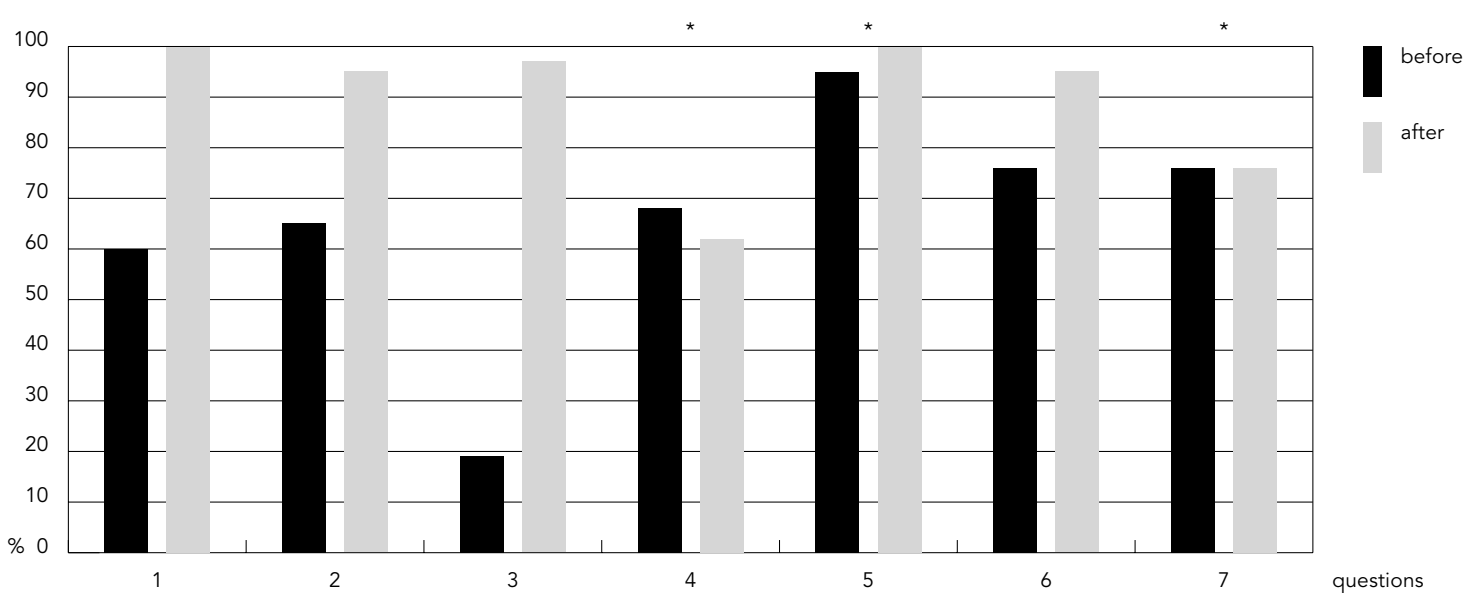

Figure 3d

Registered nurses $(n=15)$

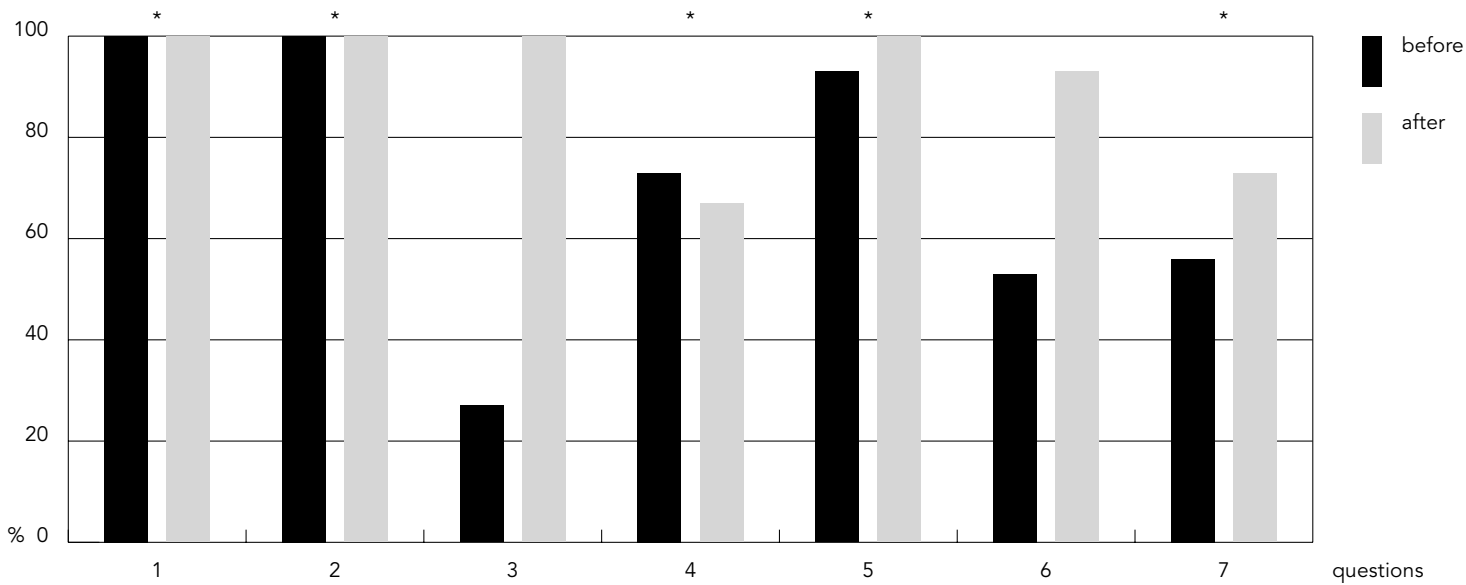

* No differences. 
Figure 4

Percentage of teachers (a), students (b), and laypeople (c) who correctly answered questions 1 to 7 before and after reading the pamphlet.

Figure 4a

Teachers $(n=126)$

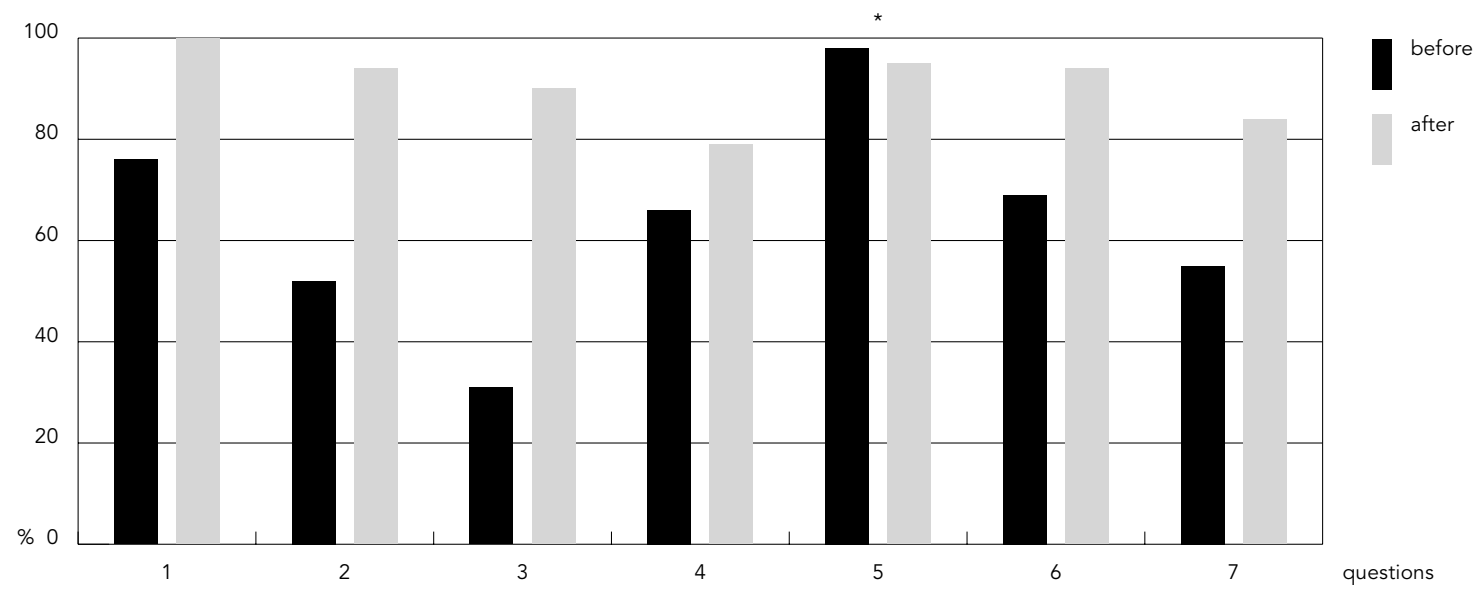

Figure $4 b$

Students $(n=223)$

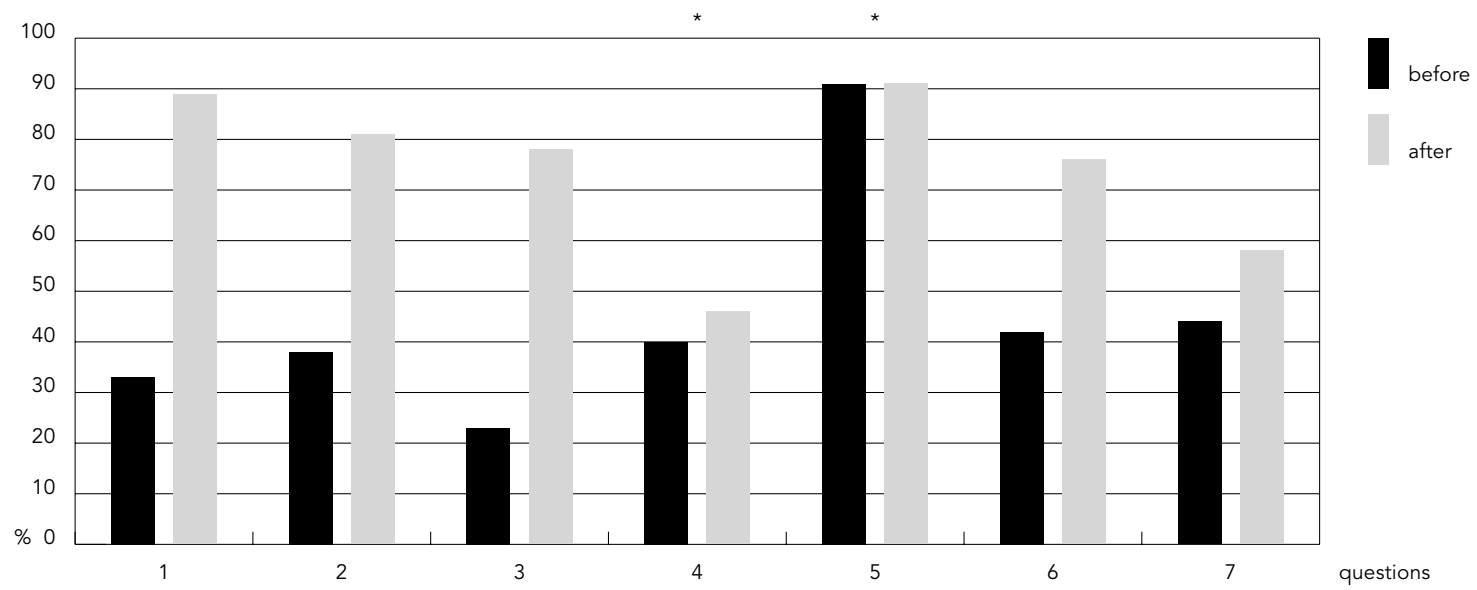

(continues) 


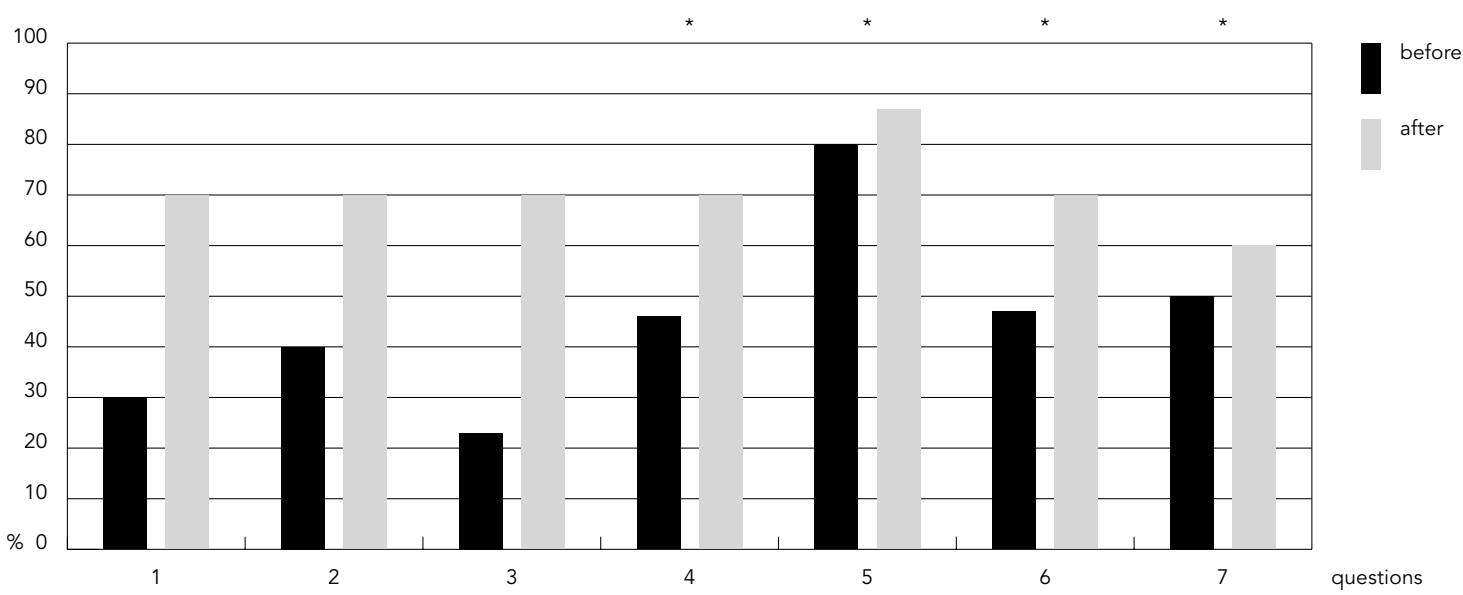

* No differences.

In an attempt to improve prevention and control of VL, a pamphlet with basic information on the disease was developed.

Considering that the primary aim of a pedagogical message is comprehension, the message should contain a signal system that is as clear as possible 11. In Brazil, informative material on leishmaniasis has been distributed in an attempt to reduce the complexity of information. Unfortunately most of these publications use inappropriate language and contain conceptual errors. The effectiveness of their information is thus clearly jeopardized 7. Although the pamphlet described in this study contains technical terms such as Leishmania, sand fly, and parasite, the information is clear enough to be understood. This was evidenced by the fact that although subjects read the pamphlet only once, the majority scored much higher after reading than before.

Prior knowledge, measured by the average percentage of correct answers in all categories, varied widely and was very poor for students and users of healthcare services. In the northeastern Brazilian State of Maranhão, which has the country's second highest incidence of VL (Fundação Nacional da Saúde. Série histórica de doenças de notificação compulsória. http://www.funasa. gov.br/epi/epi00htm, accessed on 21/Mar/2003), knowledge concerning VL, especially on the subjects of prevention and treatment, was minimal among rural and peripheral urban populations 12 .
Our findings related to the baseline knowledge possessed by registered nurses, students, and users of healthcare service confirm those of previous studies. The question-by-question analysis showed that all participants (with the exception of the zoonosis control agents) had poor knowledge of leishmaniasis symptoms. As shown in Figure 5, before reading the pamphlet, nearly $40.0 \%$ of both groups confused VL with tegumentary leishmaniasis or dengue. The low proportion of correct responses among laypersons could be explained by the confusion arising from multiple answers. However the health professional group, with at least elementary knowledge of VL, should be expected to interpret the options clearly. In this group, only zoonosis control agents showed satisfactory familiarity with VL symptoms, with $64.0 \%$ of correct answers. This is definite cause for concern. Although all these diseases cause severe disability, special attention should be given to $\mathrm{VL}$, because late diagnosis can be fatal. We speculate that in Greater Metropolitan Belo Horizonte, the high case-fatality rate for VL can be associated with the lack of qualified professionals 5 . Early detection of the disease and reporting of cases undergoing treatment are fundamental 13 and will allow control measures to be taken immediately. Having well-trained technical personnel and efficient delivery systems is important for empowering the current Family Health Program, sponsored by the Brazil- 
Figure 5

Average percentage of health professionals (group 1) and others (group 2) who gave incorrect answers

to questions 1 to 7 of the questionnaire, before and after reading the pamphlet.

Figure 5a

Question 1)

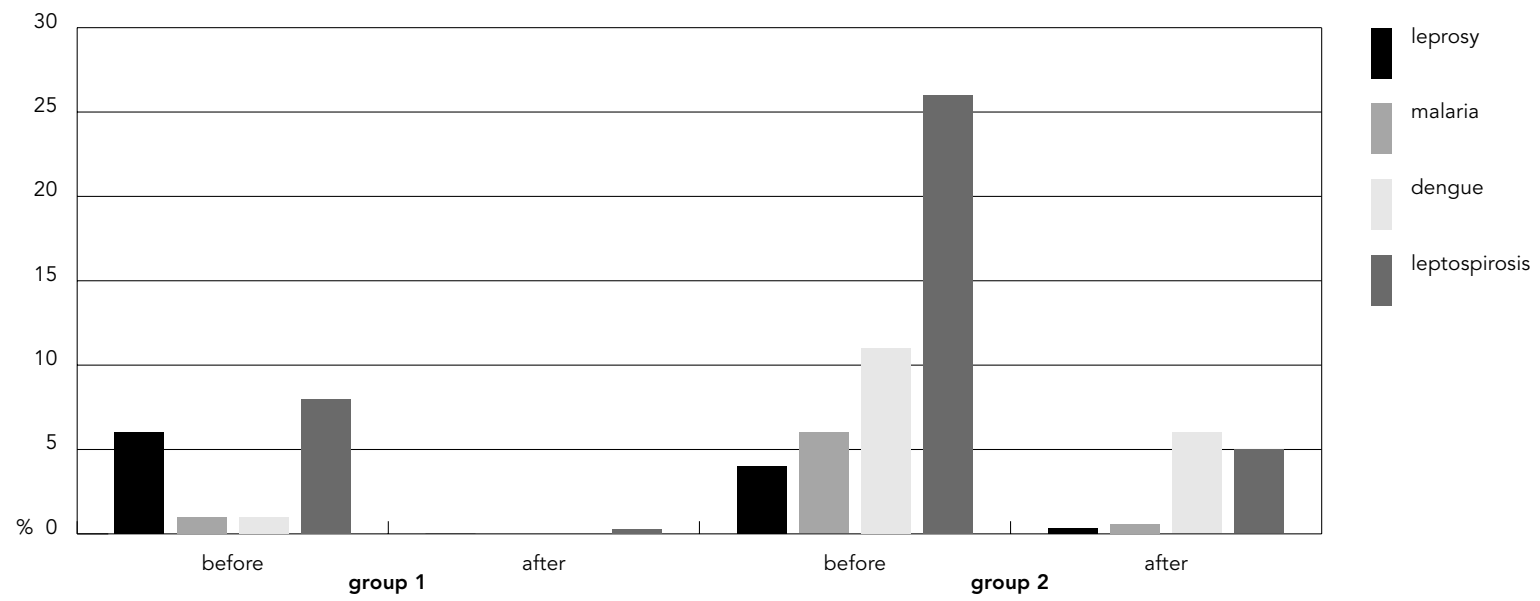

Figure $5 b$

\section{Question 2)}

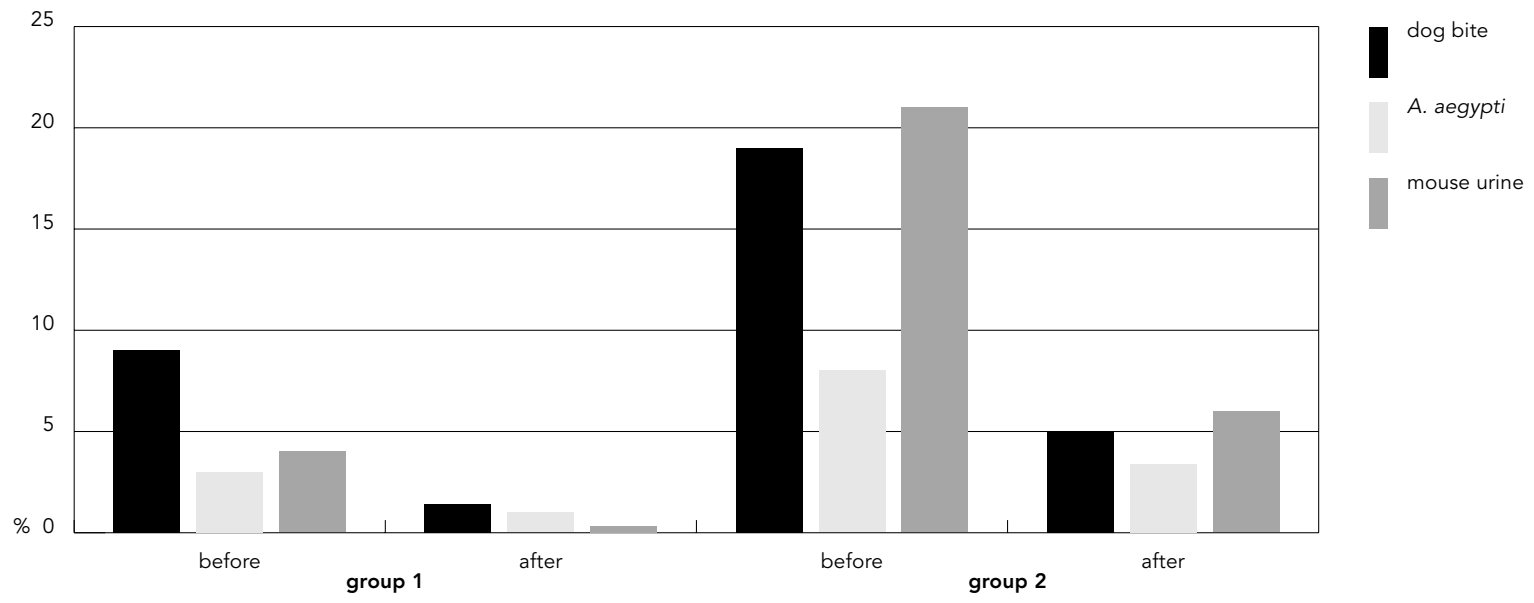

(continues) 
Figure $5 c$

Question 3)

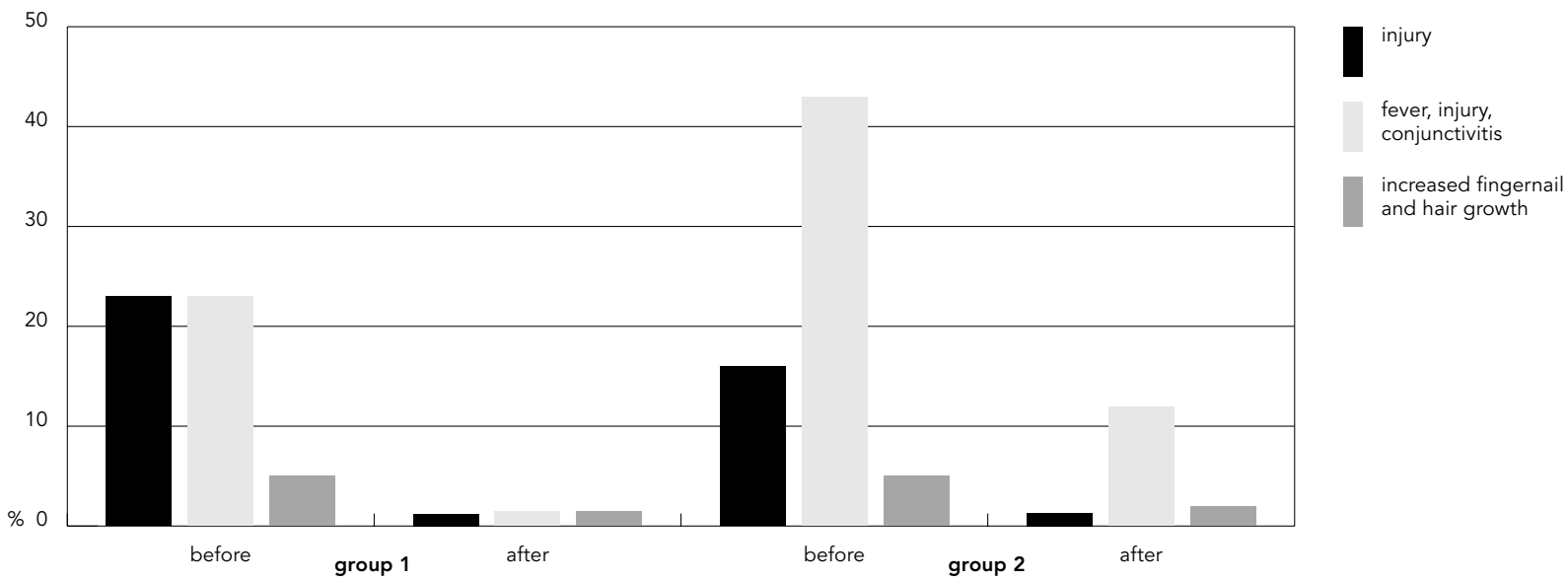

Figure $5 d$

Question 4)

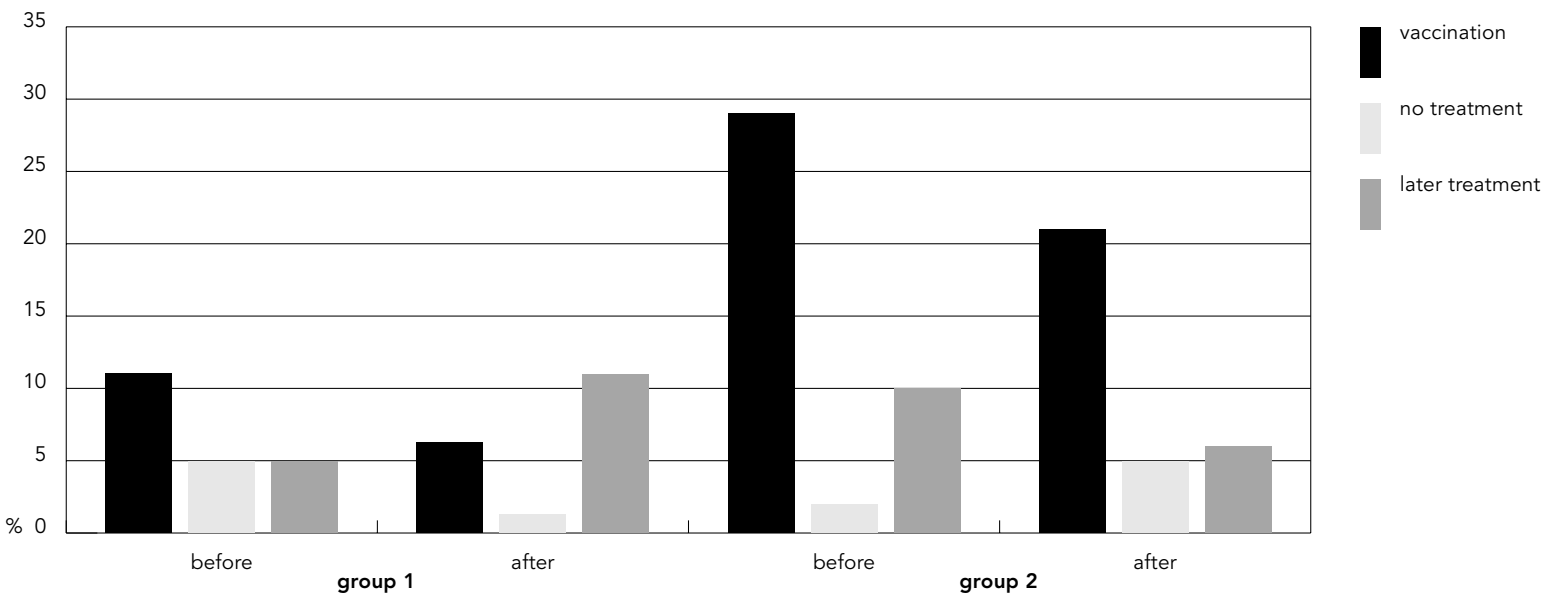

(continues) 
Figure $5 e$

Question 5)

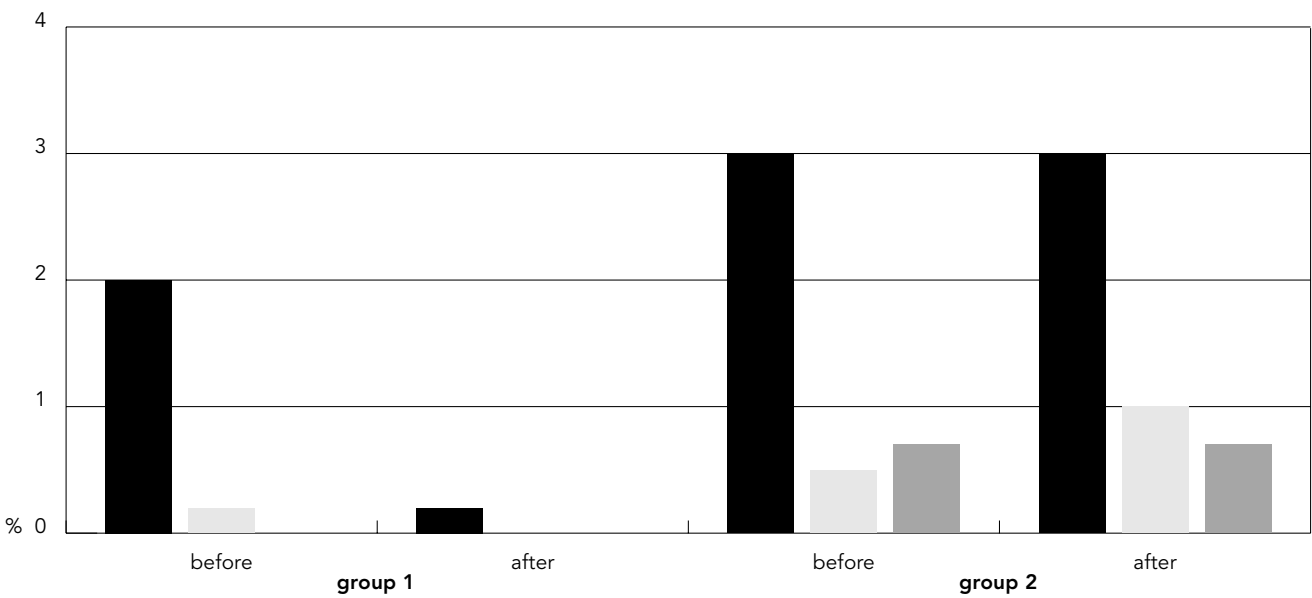

rest and liquids

fever and pain

medication

fever medication

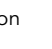

Figure $5 f$

Question 6)

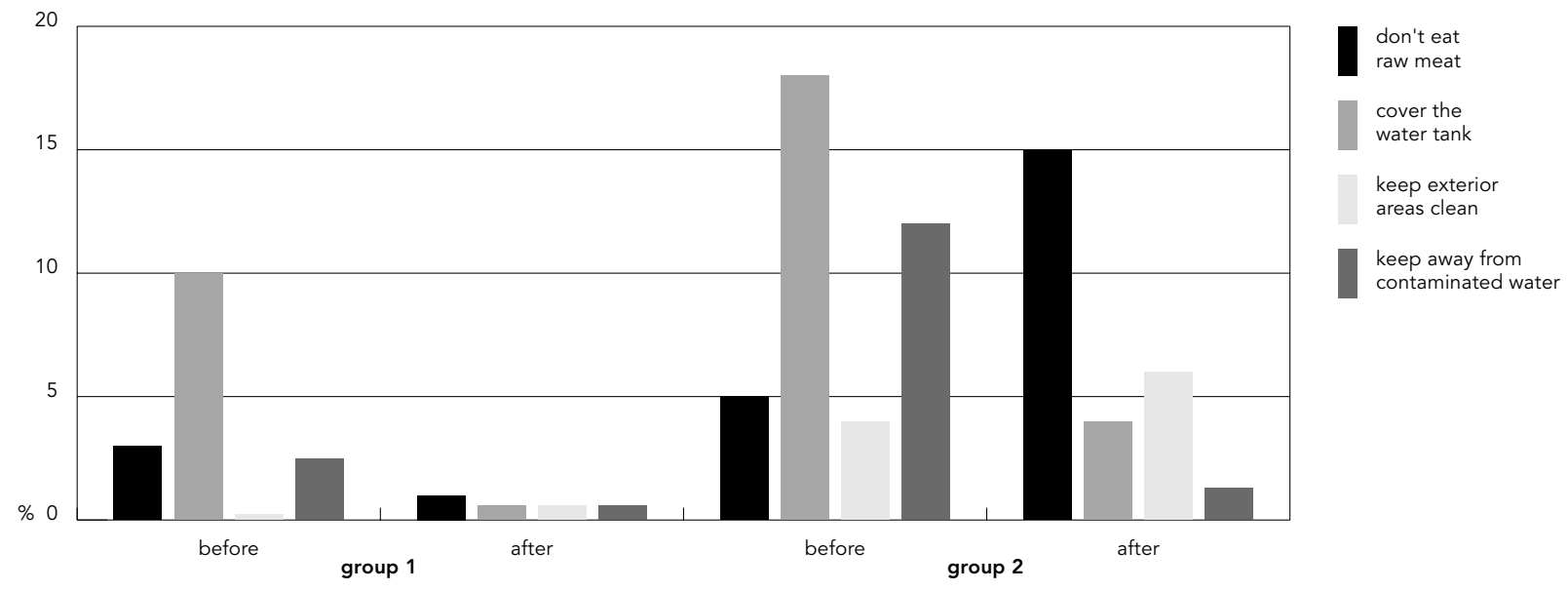

(continues) 


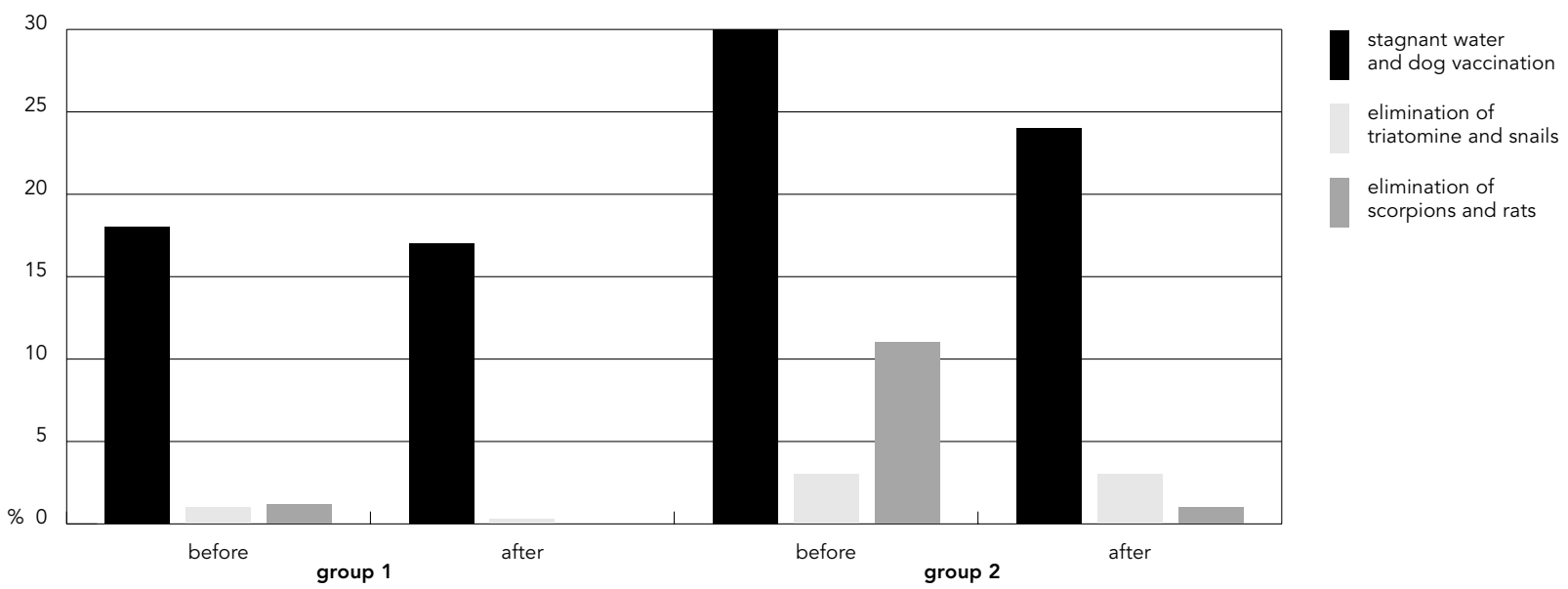

ian Ministry of Health. In this program, in which all staff members work as a network, community healthcare workers identify domestic health problems and refer patients to the program coordinator, who arranges the necessary care. Consequently, if the staff is well trained, benefits will be great for patients in particular and the program in general. In the questions related to treatment and control measures, reading the pamphlet did not change the performance of the students, users of healthcare service, or nurses. This is an indication of which sections of the pamphlet most probably need improvement. The use of a closed questionnaire may also have elicited correct or even incorrect answers. This may have been the case for the high proportion of correct answers to question 5 (What should you do when you notice symptoms of the disease?), in which high percentages of the participants chose the answer: "See a doctor". The analysis of incorrect answers before reading showed that students, users of healthcare services, and teachers confused VL with leptospirosis. After reading, even though mice were not mentioned in the pamphlet, this group contended that mice are leishmaniasis vectors. The increased confidence in answering the questionnaire after reading the pamphlet was evidenced by respondents' low proportion of non-responses and multiple answers.

In the case of leishmaniasis, dissemination of information has been one of the major tools used in health education-based control programs. However, the impact of information transmitted to the population has not been evaluated previously by government health agencies. Six months after access to information in the pamphlet, we assessed the level of knowledge retained by 65 students who had participated in this study. Using the same questionnaire, preliminary results showed no difference in the average percentage of correct answers given by these students six months after in comparison with the questionnaires given immediately after reading the pamphlet. In addition, on all topics, the profiles of incorrect answers were virtually identical (data not shown).

Although survey methods have some limitations related to validity and reliability of results, these methodologies are effective tools for collecting objective data. This study was an attempt to assess the baseline knowledge of VL, the pamphlet's capacity to transmit information, and deficiencies or inadequacies in the material. The limited number of studies on this topic made it difficult to establish parameters for precise sampling. Nevertheless, these results will provide the basis for further research on knowledge, attitudes, and practices.

The pamphlet shows great potential, as evidenced by the high proportion of correct answers after reading it. Pamphlets are generally valuable informative tools and are useful for disease control programs, but they should be used within the context of a continuing educa- 
tional process. For example, an appropriate combination of information and entertainment can increase awareness, which may in turn lead to the creation of alternative solutions and reevaluation of decision-making processes, thereby shedding light on previously overlooked factors 14 . In order to generate effective changes and strengthen control measures, health and educational measures should adhere to well-defined criteria. Such measures should also undergo systematic evaluation in order to measure their impact, and the evaluation should be preceded by scientific investigation in order to ensure that the content and presentation are consistent with the target population's cognitive potential.

\section{Resumo}

No Brasil, embora materiais educativos sejam freqüentemente produzidos como parte de programas de controle de doenças, muito pouco se sabe a respeito da eficácia desse tipo de informação. Neste estudo, o potencial informativo de um folheto sobre a leishmaniose visceral foi avaliado em amostra de 551 profissionais de saúde e 379 indivíduos da população de dois municípios da Região Metropolitana de Belo Horizonte, Minas Gerais, Brasil. Utilizou-se questionário com sete questões de múltipla escolha, antes e imediatamente após a leitura do material. O conhecimento inicial sobre a doença foi estimado pela proporção de respostas corretas antes da leitura do folheto. Entre os agentes de zoonoses, 90,0\% em média responderam corretamente às questões, nas outras categorias, a variação foi de 45,0\% a 77,0\%, elevando-se para 71,0\% a 96,0\%, após a leitura. A questão com menor percentual de acertos, antes da leitura, foi a relacionada aos sintomas da doença. Entre as respostas incorretas verificou-se que a leishmaniose visceral é principalmente confundida com a leptospirose. Após a leitura, o número elevado de respostas corretas mostrou que o potencial de transmissão da informação do folheto foi adequado.

Folhetos; Leishmaniose Visceral; Questionário; Pessoal de Saúde

\section{Contributors}

The idea for this study was by Z. M. P. Luz, who also conducted all the descriptive stages in the methodology, including the elaboration of the database, data entry, analysis of the results, and drafting of the article. V. Schall and A. Rabello participated actively in the methodological design, discussion of the results, and critical reading of the article.

\section{Acknowledgments}

The authors would like to thank the epidemiological surveillance and health education coordinators for their assistance administering the questionnaire. We would also like to thank the Oswaldo Cruz Foundation and the Brazilian National Research Council for their financial support. 


\section{References}

1. Mott KE, Desjeux P, Moncayo A, Ranque P, Raadt P. Parasitic diseases and urban development. Bull World Health Organ 1990; 68:691-8.

2. Desjeux P. Urbanization: an increasing risk factor for leishmaniasis. Wkly Epidemiol Rec 2002; 77: 365-70.

3. Costa CHN, Pereira HF, Araújo MV. Epidemia de leishmaniose visceral no estado do Piauí, Brasil, 1980-1986. Rev Saúde Pública 1990; 24:361-72.

4. Jerônimo SM, Oliveira RM, McCkay S, Costa RM, Sweet J, Nascimento ET, et al. An urban outbreak of visceral leishmaniasis in Natal, Brazil. Trans R Soc Trop Med Hyg 1994; 88:386-88.

5. Luz ZMP, Pimenta DN, Cabral ALLV, Fiúza VOP, Rabello A. A urbanização das leishmanioses e a baixa resolutividade diagnóstica em municípios da Região Metropolitana de Belo Horizonte. Rev Soc Bras Med Trop 2001; 34:249-54.

6. Schall V, Diniz MCP. Information and education in Schistosomiasis control: an analysis of the situation in the state of Minas Gerais, Brazil. Mem Inst Oswaldo Cruz 2001; 96:35-43.

7. Luz ZMP, Nacif DP, Rabello A, Schall V. Evaluation of informative materials on leishmaniasis distributed in Brazil: criteria and basis for the production and improvement of health education materials. Cad Saúde Pública 2003; 19:561-9.

8. Boruchovitch E, Schall V. Questionnaires in health education research. Advantages and disadvantages of open-ended questions. Implications for health research methodology. Ciênc Cult 1999; 51:12-6.
9. Wijeyaratne PM, Arsenault J, Murphy CJ. Endemic disease and development: the leishmaniasis. Acta Trop 1994; 56:349-64.

10. Werneck GL, Rodrigues Jr. L, Santos MV, Araújo ISM, Lima SS, Gomes RBB, et al. The burden of Leishmania chagasi infection during an urban outbreak of visceral leishmaniasis in Brazil. Acta Trop 2002; 83:13-8.

11. Levéfre F. Análise semiológica do cartaz educativo "o ciclo da esquistossomose". Rev Inst Med Trop São Paulo 1981; 23:233-43.

12. Gama MEA, Barbosa JS, Pires B, Cunha AKB, Freitas AR, Ribeiro IR, et al. Avaliação do nível de conhecimento que populações residentes em áreas endêmicas têm sobre leishmaniose visceral, Estado do Maranhão, Brasil. Cad Saúde Pública 1998; 14:381-90.

13. World Health Organization. Control of the leishmaniases. Geneva: World Health Organization; 1990. (Technical Report Series 793).

14. Schall V. Health education, public information and communication in schistosomiasis control in Brazil: a brief retrospective and perspectives. Mem Inst Oswaldo Cruz 1995; 90:229-34.

Submitted on $09 /$ Oct $/ 2003$

Final version resubmitted $07 / \mathrm{Jul} / 2004$

Approved on 21/Jul/2004 